\title{
Towards Sustainopreneurship Development at the Tertiary Level Education: A Case study on Southern University Bangladesh
}

\author{
Kazi Nazmul Huda \\ Associate Professor, \\ Department of Business Administration \\ Southern University Bangladesh \\ E-mail:knhuda@yahoo.com
}

\begin{abstract}
The concept of sustainopreneurship demands entrepreneurial actions to promote sustainable development goals and principles in business activities. The study understands the necessity of an academic curriculum that aids the business gradates to enhance their entrepreneurial skills in the light of sustainopreneurship development concepts. Key objective of the study is to propose an action-oriented model of sustainopreneurship that may enrich the existing curriculum of entrepreneurship development courses taught at the university level. The current study is based on classroom experiences at Southern University Bangladesh. The paper tries to offer a potential model of embedding sustainopreneurship in the entrepreneurship development curriculum that opens the possibility in attaining the goals of the said concept. The methodology of the study is based on qualitative research conducted through exploratory analysis. Results of the study are based on observation and the opinions of the direct stakeholders specially the students, faculties, and the management of the university.

Key words: Sustainopreneurship, Entrepreneurship, University Curriculum, Education, Tertiary Level, Innovation \& Creativity
\end{abstract}




\section{INTRODUCTION AND RATIONAL OF THE STUDY}

Entrepreneurship is an important ingredient that facilitates sustained economic growth in any economic system. It appears to be a precondition for sustainable development and could be considered as strategic equipment to ensure a balanced and non-discriminatory society. It empowers the citizens to develop a self-domain of economic activity through creative business models. According to Abrahamsson, (2006) Sustainopreneurship is the used to solve problems related to social and environmental sustainability and convert the problems into business opportunities through sustainability innovations. Sustainopreneurship demands mindsets and practices of sustainable entrepreneurship development that promotes the goal of sustainable development such as poverty eradication, child development, empowerment, annihilation of life threatening diseases. This business model asks for creative problem solving related to economic, social, and environmental sustainability. The concept is focused to aid and ensure sustainability in innovation that provides economic growth, social mobility, and environmental security.

The business organizations are the major powers for developing a sustainable world that comes through innovation and creativity (Hart 2005, Prahalad, 2004).Therefore, creating a pro- innovation and pro-sustainability organizations is a challenging task that could be overcome through materializing the concept of sustainopreneurship development as it is conceptualized in Sustainable Development Goal 2015. The concept gives a reminder to all business communities that business organizations are not out of the society and sustainability of business lies on the presence of sustainable society as well as sustainable environment. It is a provocative question that who is responsible to build sustainable business organizations. As most business models are designed for profit maximization, so how to create a sustainopreneural mindset where the entrepreneurs will search for ideas for sustainable development and entrepreneurs will be rewarded for that. Most of the entrepreneurship development models suggested the tools for business and businesspersons' sustainability and the model for world sustainability is very rare in theories and absent in practices. Most commonly discussed entrepreneurship development model of Akhoure 1977 or very new Eco System model of Daniel Isenberg (2010) and others are mostly designed to encourage, support, and sustain entrepreneurs through different socioeconomic interventions. However, how entrepreneurs should be responsible and act to sustainable development is still less explored.

Most business schools in Bangladesh have entrepreneurship development courses in their curriculums. But the questions is; do they nurse their students to cultivate creative skills to create and design a sustainable business model as suggested in sustainopreneurship concepts? The positive answer is very rare. Most business schools are prioritizing classified agenda to develop corporate practitioners not entrepreneurs or intrerpreneurs. The model of this study intends to offer tertiary level B-schools a focused based insight so that they can revise their entrepreneurship courses according to the suggestions of Sustainopreneurship model.

Southern University Bangladesh over-ambitiously endeavored through the domain of unexplored and challenging sky of concept development and testing in a prototype module of what the class lectures and curriculum expect them to learn. To complete the circle of concepttheory-practice-research, Southern University Bangladesh managed it quite in a spectacular fashion. The paper endeavors to discuss the case of the said university to improvise an action 
oriented sustainopreneurship development-teaching model to inspire and groom the students with sustainability mindset.

Sustainability has become a global issue and the declaration of sustainable development goal (SDG) indicates the seriousness of the world community to make the earth livable for the present and future humankind. Looking at the reality, the entrepreneurship development education needs to be smarten up, as the curriculum and methodology of most of the universities in the country is old fashioned and does not allow developing creative however sustainability skill to nurture sustainopreneurship among the students. Most of the entrepreneurship theories and models are formulated by considering the profit maximization goal of the company even though the profit may come at the cost of environmental and social degradation. However, it can be argued that no entrepreneurial actions can survive long by overlooking the sustainability of economy, society and environment. Thus, it is necessary to start from the root by redesigning entrepreneurship development curriculum aligning the concept of sustainopreneurship such that future entrepreneurs will focus not only towards profit maximization but also towards the sustainable development issues. The universities will nurture a generation of business graduate to cherish innovation and creativity to solve world problems through entrepreneurial actions. In this explorative paper we shall try to propose a dynamic model with necessary steps and interventions to educate future entrepreneurs the concept of sustainopreneurship.

\section{LITERATURE REVIEW}

Modern concept of entrepreneurship is all about exercising creativity in business activities, product development, process development, problem solutions, and change management at large(Schumpeter 1934, Drucker, 1964, Rahman, 1997, Robinson, 2004). Main focus of entrepreneurship development is to develop capacity of innovation in a potential or existing businessperson commonly termed as entrepreneur. The concept of sustainopreneurship is not out of creative area; here an entrepreneur will exercise innovation for a noble cause mostly for socioeconomic development and environmental protection and most simplified form of the concept is "entrepreneurship and innovation for sustainability - "Business with a Cause" (Abrahamsson, 2006). The key issue here is innovation for sustainable development (Gerlach, 2003). Sustainopreneurship warrants voluntary actions for pro-active change in business practices through innovative solutions of problem or exploring opportunities on poverty, health and sanitation, recycling, world peace and justice, human security issues etc. The concept merges entrepreneurship with social and ecological development and to some extent is similar to social entrepreneurship suggested by Dr. Muhammad Yunus (Abrahamsson, 2006). Sustainability concept refers to entrepreneurial or intrepreneurial approaches that aids an integrated development of social, environmental, and economic issues that helps an organizations to continue its business for the long run (Schaltegger, \& Burritt, 2005; Whiteman et, al, 2013). According to Abrahamsson (2007), sustainopreneurship concept should work in the area of health, education, entrepreneurship development, digital unification and sustainable distribution of energy. Author also argued that any kind of entrepreneurship may not be enough to attain the sustainable development issues rather a holistic mindset, complexity, urgency and ingenuity, are necessary for creative solutions for real-world results. 
Entrepreneurship Education is a blend of both academic knowledge and practical skills that to prepare young people to foster entrepreneurial attitudes and competencies, awareness of career opportunities, above all contributing to the development and prosperity of the society (UNESCO).The curriculum of Entrepreneurship Education should achieve more interest, joy, engagement and creativity among students (Johannisson, 2010, Lackéus, 2013). According to Welsch (1993) entrepreneurship education has taken a mature structure and have become most popular and innovative part of business curriculum and most significant academic discipline of economic development. But on the other side, business education are too much oriented to theory, tools, concepts, models and quantitative analysis and too little emphasis is given on qualitative issues and entrepreneurial activity (Derman, \& Levin, 1994).The author also mentioned that, business schools give much emphasis on bureaucratic management of academic activities and as a result the educators are living is an unreal world. According to Sexton and Kasarda, (1992) entrepreneurship education lacks an accepted paradigm or theories, which can assist the educators to engage in realistic entrepreneurship development activity. However, no such attempt has ever been taken to revise the curriculum of entrepreneurship courses according to the needs of the real life economy, society, and environment. It is also unclear that, at what this education impacts on the graduate students and there is a lack of consensus that what type of entrepreneurship education actually applicable at the time of practice (Pittaway, \& Cope, 2007).

Over the past few years is mark able necessity has been observed at university level on the issue of social innovation and social entrepreneurship and the educators are facing challenge to figure out the responsibilities of social entrepreneurs and how a course could be organized to add this new terms and contents (Lawrence, et. al. 2012)

From the literature, it is found that the concept of sustainopreneurship is a blend of entrepreneurship and sustainability where a sustainopreneurs should have vision to make the world a better place for living by applying the innovative ideas to challenge the world's sustainability problems. There is enough literature on entrepreneurship education but a gap is observed on how to educate sustainopreneurship.

\section{OBJECTIVE}

Key objective of the study is to propose an action-oriented model of sustainopreneurship education that may enrich the existing curriculum of entrepreneurship development courses taught at the university level.

\section{METHODOLOGY}

The methodology of the study is based on qualitative research conducted through exploratory analysis. Secondary information were firmly drawn from previously published research literatures, related articles obtained from academic journals and curriculum of entrepreneurship development of different business schools located in Chittagong the second largest city and the commercial capital of Bangladesh. For preliminary information about the current trends of entrepreneurship development education and prospect of applying sustainopreneurship model, data have been collected through separate focus group discussion (FGD) sessions with the students, faculty members, and management of the university. Another discussion session was 
organized in the form of FGD composing students and graduates of other business schools of Chittagong to understand about the model of entrepreneurship development courses..

Four focus group discussions were conducted in this study. First, one with the former students those who are entrepreneurs and intrepreneurs. Second, one was conducted on the BBA final semester students completed the entrepreneurship development course. Third FGD was with the faculty members of Business Administration whom have minimum five years of teaching experience and takes the classes of senior students of the program. Most of them having corporate job experience and some are doing side business. All the responding faculty members are perusing higher degree research. Some of the faculties were members of the judge's panel of EDF and business plan competition (Phase 7). Responding Management people are highly qualified academically and having minimum fourteen years of experience in managing university and also academic curriculum design. Number of respondents in each FGD was minimum six people.

\section{MODEL DEVELOPMENT}

Southern University Bangladeshis an unique institution that values the development of sustainopreneurship among the young business graduates through exercise oriented Entrepreneurship Development Program (EDP). This program was introduced in the year 2003 as a regular activity of the academic curriculum to inspire the students of entrepreneurship development course to be confident and skilled to start a small business with the sustainopreneurial motivation instead of making tireless endeavors of searching for jobs. From the literature review, it is clear that two major interventions are obvious to teach sustainopreneurship. First, the students should be developed with creative thinking skill that may help them to be innovative, and they should be allowed and inspired to use the skills for sustainable development through business activities. Keeping the aforementioned challenges in mind, the author has designed a seven-phase program of sustainopreneurship development that may inspire the student to think and act sustainably in their businesses as sustainopreneur or corporate sustainopreneur (intrepreneur) as employee.

\section{Phase 1: Inspiring}

The course starts with sharing success stories of local and foreign entrepreneurs in the form of case studies and presentation. Success stories of global entrepreneurs like William Henry "Bill" Gates III, Steven Paul "Steve" Jobs, Warren Edward Buffett, Sir Richard Charles Nicholas Branson and Dr. Muhammad Yunus to local entrepreneurs like Mr. Sheikh Akij Uddin, Mr. Sufi Mizaur Rahman, and some successful young entrepreneurs of Bangladesh were discussed in the class to inspire the students to take the challenge of entrepreneurship and change their mind set to job creation instead of job searching. Former students of Southern University who became successful entrepreneur were invited to interact with the current student of the course. This part of the model is to touch the emotion of the student to create an entrepreneurial spirit among them. Cope (2011), in his research on entrepreneurship education have emphasized the emotional part of entrepreneurial education to inspire the students. Special presentations on sustainable development issues are organized and social workers working with the sustainability concept were invited in this regard. 


\section{Phase 2: Team Formation}

Teamwork is an essential management practice to nurture creativity and successful teamwork enhances creative thinking and skills for innovation (Hoegl, \& Parboteeah, 2007). A learning team comprises of five students were formed to work closely to perform the activities and events of sustainopreneurship development programs. Effective teamwork helps in sharing of minds to develop a creative product and formulate business plan. Team members are organized as business partners and develop a partnership contract. The course teacher according to their previous results and classroom performance chooses team leaders. They are empowered to choose the team members from their mates. Teamwork is exercised in the classroom. The teams are allowed to sit in roundtable formation to solve cases and preparation for the next phase.

\section{Phase 3: Creative thinking skill development}

Case studies on successful Bangladeshi start-up entrepreneurs are asked to allow the students to think critically and to go into in-deep of the subject matter. Through 20 minutes brainstorming session in every class, the students learn to scan the environmental issues including sustainability factors. Marketing $3.0^{1}$ concept of Dr. Philip Kotler (2010) is also taught to teach sustainable marketing practice.

\section{Phase 4: Internship on Entrepreneurship}

At this stage, the learning team is attached with a micro/small business entrepreneur for two weeks. In this phase, the students are assigned to develop a presentation on entrepreneurs autobiography and work process. Participants of the program learn about the types of entrepreneurship, challenges of entrepreneurship, key success factors, social contributions, and achievements.

\section{Phase 5: Hands on Training (Workshop on Business Plan writing)}

At this stage, all the learners receive the assistance to develop a practical business plan. Industry experts on preparing business plan (mostly an executive of a financial institution) are invited to conduct a daylong session in the form of seminar/workshop/training. Green business ${ }^{2}$ planning and its scopes are also highlighted in the session.

\section{Phase 6: Developing Business Plan}

After receiving the training, the learning teams are assigned to develop a business plan. The contents of the plan include industry analysis, marketing plan, financial plan, budgeting and operation plan. It is mandatory to include the sustainability issue in every part of the content.

\footnotetext{
1 The new model for marketing-Marketing 3.0-treats customers not as mere consumers but as the complex, multi-dimensional human beings that they are. Customers, in turn, are choosing companies and products that satisfy deeper needs for participation, creativity, community, and idealism. Value based marketing practice.

2 A business functioning in a capacity where no negative impact is made on the local or global environment, the community, or the economy. A green business will also engage in forward-thinking policies for environmental concerns and policies affecting human rights. (Business Dictionary .com)
} 


\section{Phase 7: Entrepreneurial/Sustainopreneurial Laboratory Training}

This is the final stage when a student receives the full flavor of sustainopreneurship and the spirit of doing a business is developed. By the direct assistance of the department of business administration, the learning team who are called as 'novice entrepreneurs' accepts the challenge to develop business models to start a small business with the aim to promote sustainopreneurship among them and others. The whole batch of students of entrepreneurship development course engages themselves in organizing a mini trade fair termed as Entrepreneurship Development Fair (EDF).

Every EDF starts with a theme that directly promotes the social development and social responsibilities of business emphasizing supreme priority to polish the business graduates with sustainopreneurial mindsets. Since 2007 the BBA graduates of Southern University have arranged fourteen EDF with the sustainability themes like; Trade Fair on Indigenous Products Marketing (To eradicate poverty with self sustained initiative), Social Entrepreneurship Development Fair(To promote the concept of social business), Young Entrepreneurship Fair(Entrepreneurship for Empowerment)Sustainable Entrepreneurship Development (Business Sustainability through social development), Green Entrepreneurship Development(To Heal the World), Digital Entrepreneurship Development Fair(Promoting Digitalization), Grassroots Entrepreneurship Development(Micro Business to Eradicate Hardcore Poverty), Fusion Food Entrepreneurs hip(Entrepreneurship for Healthier Life), Fashion Entrepreneurship(Sustainable advantage through creativity in fashion industry), 11th EDF (Entrepreneurial actions to achieve MDG), Entrepreneurship for Child Development(Promoting Children's Rights and Business Principles of UNICEF).13th EDF of Smart Kart Entrepreneurship (Encouraging Micro Business; Empowering Youths)and 14th Global Entrepreneurship Development Fair (Bridging Heritage; Exploring Global Opportunities)

The learning and experiencing area of this EDF program facilitates BBA students to learn team work, sustainable business planning, brainstorming exercise for innovation, product development, market research, customer orientation and sales management and other management and organizing skills to develop sustainopreneurship qualities among them. The program ends with a competition and the participants are awarded in four category, i.e. "The Most Decorated Stall," "The Best Product Development" (in compliant with the sustainability theme), "The Best Business Plan" and "The Best Entrepreneur/Sustainopreneur." External judge's panel whom are young entrepreneurs or successful intrepreneur assesses the performance of the learning team. Successful industrialists of Bangladesh are invited as chief guest of the inaugural and closing sessions.

\section{DISCUSSION}

At the time of FDG, the respondents were asked to critically analyze the proposed model. The respondents opined their experiences and outcomes of the events and interventions. The faculty members also contributed suggestions to improve the model. The model was highly appreciated by the management of southern university Bangladesh. The events of the model were merely a classroom program science 2010. At present, the model is institutionalized as regular curriculum of the BBA program of Southern University Bangladesh. 
Most of the students responded positively about the model. Commonly, they emphasized on the strengths of the model that it give them a practical experience and on the other side the joy and fun of learning in a collaborative manner. It motivates them to act creatively and encourage to become innovative. They focused on their experiences of short internship program and EDF especially. However, the journey was stressful for time pressure but it gives them a lifeline experience to work independently and gives them energy to contain the pressure of doing big projects. Some of them opined that entrepreneurship development course should be offered at the middle of the BBA program so that they could set their mind to build their career as entrepreneur little early. Selected comment of the students stated below.

Entrepreneurship Development program is a milestone of my career as an entrepreneur. I was highly inspired by the "Bests product development award" that I have received participating in EDF. The most important outcome of the course is, it helped me to take challenge and to be innovative.

Masudul Alam, Entrepreneur, Maya Accessories (BBA 25th Batch).

The course has given me a lot of strength and confidence to face challenges and to take initiative. It helped me to be innovative indecision-making.

Muhammad Mahmud Hossain Mamun, Corporate Entrepreneur "Innovation Award for Contributing in Eureka Idea Program 2015" Area Manager, Robi Axiata Limited (BBA 25th Batch).

As a student of Business administration, our primary goal should become an entrepreneur. In other word our aim should be like to take risk for establishing a new venture or business in order to create utility for the welfare of our society as well as for ourselves and leave the thought of working for others in order to help them make profit just in return of some monthly remuneration. Entrepreneurship Development course teaches us to seek out for opportunities, taking on challenges, becoming a leader and throughout the process, building a new idea that could change the society, nation as well as the entire world.

Isfak Kabir, Banker, (BBA 29th Batch)

"The course Entrepreneurship Development reveals to us the enormous prospects in the business world. It helps us unlock our entrepreneurial potentials while having a look into the real life experiences of successful business people. The Entrepreneurship Development Fair arranged as a practical part of the course is almost a simulation of a real business world, which is really helpful. On the whole, I would say, undergoing the course helped me learn a lot on sustainable development issues was also a wonderful experience.

Soad Ali, Student (BBA 42nd Batch)

Entrepreneurship Development course allowed me to gain firsthand experience in a wider horizon. At the time of internship on entrepreneurship program provided me an opportunity to be with a real entrepreneur and learned how to sustain a business keeping the social responsibility in mind. Taking part in the "Entrepreneurship Development Fair" gave me the opportunity to become an entrepreneur for a while- coming up with a new product idea, taking measures to 
develop the product child friendly, preparing a business plan, managing a team, coming up with decisions on short notice and mostly how we could contribute in socioeconomic development.

Mohammad Imraj Kabir, Student (BBA 40th Batch).

Though the faculty members have appreciated the models success in Southern University, but some of them questioned about its validity and applicability as an universal practice. The faculties have opined on the issue as it provides a direct academic impact to the student and society at large. The model helps to acquire real operational and market knowledge. It ignites creativity among the students through knowledge sharing among the teachers and students. The sustainable development issue of the model helps the students to value the social and environmental development of business objective. Some faculties have advised to take feedback of the program for continuous improvement of the model. Department to keep the record of the students who became entrepreneur and may come up some helpful mechanism to support their business sustainability by taking learning and development projects.

Entrepreneurship Development course prepare students as business entrepreneurs with deeper knowledge of business challenges as presented from the angle of the both the entrepreneur and the professional manager. Student's participation in "Entrepreneurship Development Fair" helped the students to experience with the practical aspects like social business and sustainable development. In addition, I believe, if the students obtain opportunity to demonstrate their acquire knowledge and skill in broaden arena than it can add more value in the process of development themselves as entrepreneur. Field trip to villages may facilitate to learn and generating ideas on sustainable development.

Rehnuma Sultana Khan, Assistant Professor, Southern University Bangladesh

"The fundamental objective of learning is to familiarize the learner with those things that they really need in practice. Southern University Bangladesh is successfully pointing out that notion for almost 8 years. It follows very standard procedure of encouraging entrepreneurship, which is also embedded in the course work and is a significant learning experience for the students of the Final year of the undergraduate program. Following this procedure many universities in Bangladesh has successfully encouraged entrepreneurship and it holds potential for others to fully utilize its capabilities.

Mehedi Shahnewaz Jalil, Lecturer, Southern University Bangladesh

The management of the university is very positive about the model. Entrepreneurial/ Sustainopreneurial Laboratory Training is a regular event conducted and partially sponsored by the university. University Trusties, whom are basically industrialists visits the program to inspire the young entrepreneurs. The event is planned as a festival of the university. Business leaders of the country and Development Entrepreneurs are invited as guest of honor on the occasion.

Entrepreneurship development Course of Southern University Bangladesh is quite a vibrant and gaudy subject to make it into reality. The case is different in this spectrum, where students learn in the class, conceptualize, and develop in practice real-time manner. Students 
do make their own project profile like any other business entrepreneurs, make products or services to market and sale, not to mention facing the real customer in a professional term. The organized entrepreneurship fair have been regularly held in the University campus focusing new ideas, business concept and grilled by the experts inquiries from renowned business houses and academics. The education contributes quite fruitfully to the students' life feeling the real business world before being involved in reality. The experience students gather will hopefully give them impetus and self-confidence boost while facing the tough new world order where sustainability matters above all.

Mr. Rezaul Karim, Controller of Examinations, Southern University Bangladesh

Entrepreneurship's teaching philosophy is the belief that active and experience-based learning is most effective in transforming students, faculty and researchers into innovative thinkers, achiever and to act as a social reformer. The Entrepreneurship program at Southern has designed an exciting variety of out-of-classroom opportunities to see innovation, interact with it, challenge it, and lead it.

Mr. Sarwar Jahan, Founder, Southern University Bangladesh

\section{Outcome of the Model}
- Inspires Entrepreneurship
- $\quad$ Encourages Creativity \& Innovation
- $\quad$ Foster Risk taking.
- $\quad$ Event Management skill
- $\quad$ Teamwork \& Team Management
- $\quad$ Encourage Social Responsibility

\section{Limitation of the Model}

- $\quad$ Lack of Feedback

- $\quad$ Tracking \& Support

- $\quad$ Recordkeeping

\section{RECOMMENDED MODEL}

Sustainopreneurship education should be an action oriented and carefully planned curriculum for the business students that will infuse the entrepreneurial skills like innovation and creativity one side and the spirit of sustainable development of the world on the other. According to the discussion on the model with the stakeholders, two additional phases are included in the proposed model. Maximum respondents have commonly opined regarding the feedback issue. Scope should be kept to take immediate feedback of the performance of the events included in the model and the learning outcome of the students. There should be an institutional capacity to keep the record of the students whom became sustainoprenure and their stories as case for future reference. An independent Social Communication Sites for electronic networking could be developed to connect the entrepreneurs and for digital record keeping. An institutional capacity should be developed as International Institute of Sustainopreneurship/ Center for Sustainopreneurship Development to provide assistance to the novice sustainopreneurs for 
their business sustainability. Based on the aforementioned recommendations, the improvised Sustainopreneurship education model is shown in figure 1.

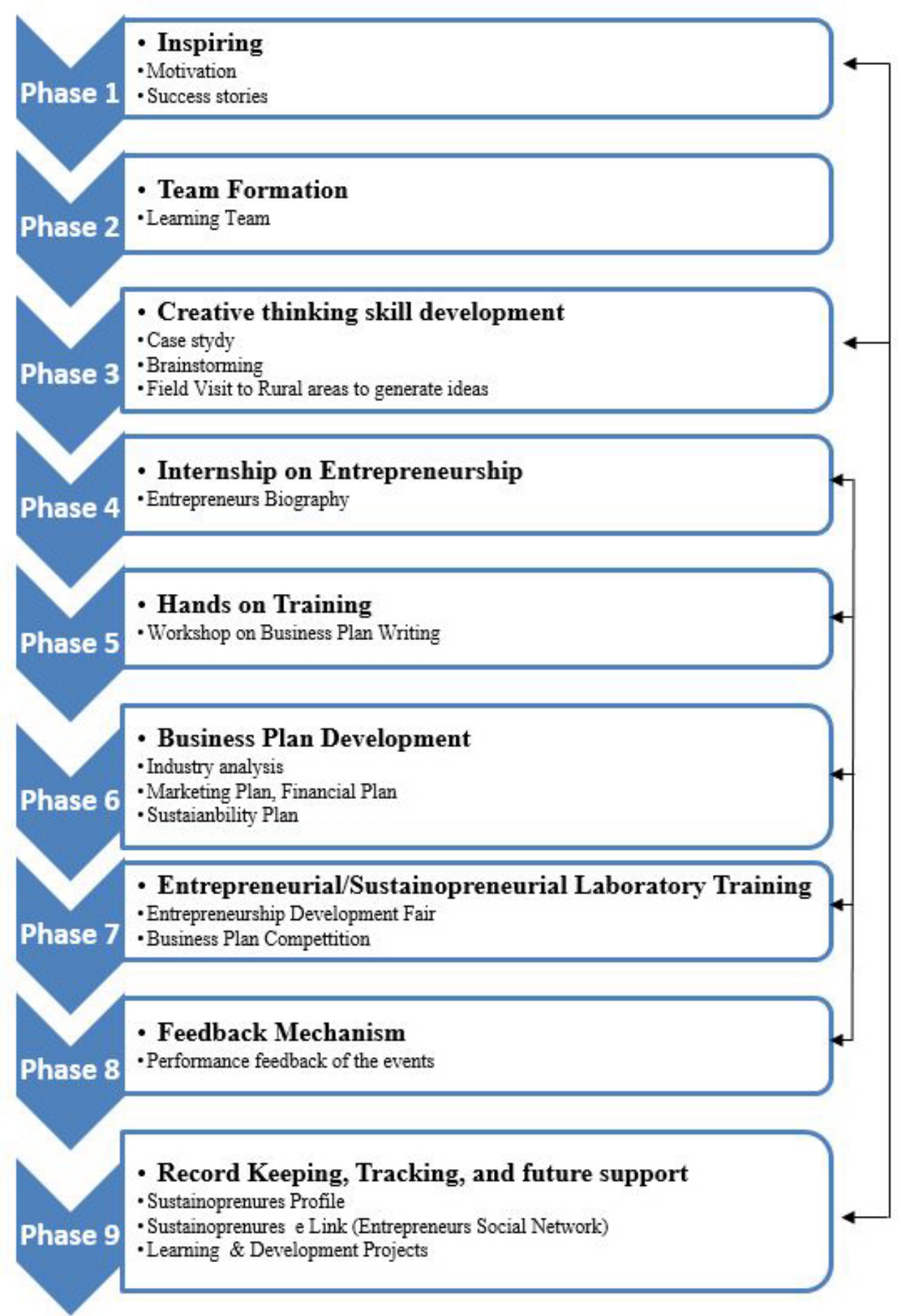

Figure 1: Sustainopreneurship Education Model (Source Author) 


\section{CONCLUSIONS}

Sustainable development is an imperative part of Development Discourse for the existence of humanity and the sustainopreneurship concept that may address some of important issues for achieving the goals of sustainable development. This paper proposed a model for Sustainopreneurship curriculum development as tested at Southern University Bangladesh to ignite the spirit of sustainopreneurship in the heart of the upcoming generations. Even though, the validity of the model has not been tested empirically, the qualitative outcomes of the model cannot be ruled out, the model has been classroom tested for last eight years. The study also suggested the issues of feedback and record keeping mechanism to track and assess the outcome of the model. The success of this model cannot be measured is a short run. The model may not give some visible immediate result in such an environment where glittering corporate culture have overruled the initiative of entrepreneurship and the jobs security issues have paralyzed the spirit of risk taking. The implacability of the concept may look far away. Nevertheless, the role of the proposed model might be the beginning in the process of practicing sustainopreneurship among the new generation to address the issues of sustainable development in the long run. Future study could be on empirical research in identifying potential of the model in achieving the goals of sustainable development by meeting the challenges of sustainopreneurship education. 


\section{BIBLIOGRAPHIC REFERENCES}

Abrahamsson, A. (2006). Sustainopreneurship-business with a cause. Science for sustainable development starting points and critical reflections. Swedish Society for Sustainable Development, VHU-Uppsala, 21-30.

Cope, J. (2011). Entrepreneurial learning from failure: An interpretative phenomenological analysis. Journal of Business Venturing, 26(6), 604-623.

Derman \& Levin, (1994). Extracted from Van Vuuren, J. J., \& Nieman, G. (1999, June). Entrepreneurship education and training: A model for syllabi/curriculum development. In 44th ICSB World Conference Proceedings.

Gerlach, A. (2003). Sustainable entrepreneurship and innovation. Corporate Social Responsibility and Environmental Management, 29-30.

Hart, S. L. (2005). Capitalism at the crossroads: The unlimited business opportunities in solving the world's most difficult problems. Pearson Education.

Hoegl, M., \& Parboteeah, K. P. (2007). Creativity in innovative projects: How teamwork matters. Journal of Engineering and Technology Management, 24(1), 148-166.

Johannisson, B. (2010). The agony of the Swedish school when confronted by entrepreneurship. Creativity and Innovation: Preconditions for Entrepreneurial Education, Tapir Academic Press, Trondheim, 91-105.

Kotler, P., Kartajaya, H., \& Setiawan, I. (2010). Marketing 3.0: From products to customers to the human spirit. John Wiley \& Sons.

Lawrence, T., Phillips, N., \& Tracey, P. (2012). Entrepreneurial Education, Stanford Social Innovation Review, November 16

Prahalad, C. K. (2004). The Aravind eye care system: delivering the most precious gift. The fortune at the bottom of the pyramid: eradicating poverty through profits.

Pittaway, L., \& Cope, J. (2007). Entrepreneurship education a systematic review of the evidence. International Small Business Journal, 25(5), 479-510.

Robinson, J. (2004). Squaring the circle? Some thoughts on the idea of sustainable development. Ecological economics, 48(4), 369-384.

Schaltegger, S., \& Burritt, R. (2005). Corporate sustainability. The International Yearbook of Environmental and Resource Economics 2005/2006, 185.

Sexton, D. L., \& Kasarda, J. D. (1992). The state of the art of entrepreneurship. Thomson SouthWestern. 
Whiteman, G., Walker, B., \& Perego, P. (2013). Planetary boundaries: Ecological foundations for corporate sustainability. Journal of Management Studies, 50(2), 307-336.

Welsch, P. H. (1993). Entrepreneurship education and training infrastructure: External interventions in the classroom. 